\title{
EFFECTS OF LEADERS-FOLLOWERS EXCHANGE (LMX) ON ORGANIZATIONAL COMMITMENT AND TURNOVER INTENT IN HOSPITALITY AND PUBLIC SERVICES
}

\author{
Tatjana Vanić ${ }^{1}$ \\ Igor Stamenković \\ Tamara Gajićs ${ }^{3}$
}

DOI: https://doi.org/10.31410/tmt.2020.525

\begin{abstract}
Based on the specifics of the selected service sectors - hospitality and public, it is clear that the role of leaders significantly varies. Antecedents for achieving organizational and individual goals include a quality relationship between leaders and followers (supervisors and subordinates), making it possible for an organization to be functional and successful and employees satisfied at work. Although the concept of leadership is as old as human civilization, numerous multi-annual researches and thousands of studies have not yielded with a clear idea of what the leadership is and how best the organizational and individual goals could be achieved. This paper focuses on the effects of the quality of leaders - followers exchange to organizational commitment and turnover intent (intention to leave).
\end{abstract}

Keywords: LMX, Organizational commitment, Turnover intent, Hospitality sector, Public sector.

\section{INTRODUCTION}

L eadership is an extremely complex issue and therefore viewed from different aspects of social life, power, politics, trust, groups or organizations. As concluded by Northouse (2001) leadership can be categorized into two groups. The first group focuses on the characteristics and behaviour of leaders and followers, while the other group focuses on the interaction and relationship between leaders and followers. The definitions of leaders and the theories of leadership have changed over time, depending on variable that is taken for analysis. Among them there is a certain degree of cohesion and researchers are trying to form a theory in which all the positive aspects will be maximized and possibly negative aspects will be minimized (Graen \& Ulh-Bien, 1995).

Depending on the type of sectors in which the research is conducted a number of specificities may arise due to various approaches applied by leaders towards their employees. Many researchers conclude that the quality of LMX relations depends on many factors. However, the specificity of the service sector is not highlighted sufficiently in those researches.

The hospitality sector consists of production and sales in hotels and restaurants on the one side, and travel agencies and tour operators on the other side, but also of public activities such as providing the necessary conditions and infrastructure for a variety of leisure activities (municipal services, museums, cultural or historically valuable buildings, theme parks, etc.). Due to many factors (working conditions, promotion, communication skills, relations between users and services - treatment of the service part of the job, good manners, etc.) tourism is character-

\footnotetext{
1 City Administration for Economy - City of Novi Sad, Rumenačka 110a, 21000 Novi Sad, Serbia

2 Department of Geography, Tourism and Hotel Management, Faculty of Sciences, University of Novi Sad, Trg Dositeja Obradovića 3, 21000 Novi Sad, Serbia

3 Novi Sad School of Business, Vladimira Perića - Valtera 4, 21000 Novi Sad, Serbia
} 
ized by frequent changes in staff members. Human resources in the hospitality sector are most important, and their specificity is reflected in the fact that they have a long-term effect on the organization's business operations, they have the development capacity and are associated with all business functions.

The government or public administration, or only the administration, is the term that implies regular activities carried out by the state or province or local government (municipality). The public sector is a very complex system that involves the participation and coordination of numerous entities in achieving common goals - the functioning public sector.

\section{LITERATURE REVIEW}

\subsection{LMX}

In the early 1970s, the trends in the study of the process of leadership were revised and it was suggested that the impact of a two-way process between leaders and followers should be recognized as the implication of trade relations (Hollander \& Julian, 1969). In contrast to the earlier theories, the new study was presented that was called the theory of leaders and followers exchange. The significance of LMX theory as one of the most influential theories of leadership is suggested by a number of studies that have been carried out over the past four decades (see more in Day \& Miscenko, 2015). From vertical dyadic relationship (Dansereau, Grean \& Haga 1975; Grean \& Cashman 1975; Grean 1976) and the theory of social exchange (Wayne \& Green, 1993) to the relational leadership (Uhl-Bein, 2006), the analysis of quality of leaders-members exchange has passed several phases from the standpoint of individual and organizational correlates.

LMX theory research began with the analysis of the role of the exchange, where the focus was on a variety of two-member interactions (dyadic) between the leader and follower in which the leader did not develop the same connection (relation) with each of the employees. In earlier literature, the research of antecedent's pre-establishment model of leader-member exchange was at the level of individual characteristics (personality, similar characters, etc.). The initial phase of LMX development was also confined to variable individual characteristics (Dienesch \& Liden, 1986). Grean and his associates (1995) base the development of LMX on the characteristics of employment, because the nature of work has a certain influence on the development of exchange between the leaders and followers, which results in different outcomes. For example, a high level of LMX improves the sense of mutual obligations, reciprocity (Liden et al., 1997) and emotional attachment between the leader and follower, and such connections are social. Labour relations are based on social exchange (Erdogan, Liden, 2002) characterized by loyalty, commitment, support and confidence (Cropanzano \& Mitchell, 2005), as opposed to economic exchange, characterized by employment contracts (Blau, 1964).

Studies that relied on social exchange argued the nature of the relationship between the quality of LMX and its outcome (Erdogan, Bauer, 2015). Numerous LMX studies focus on the outcomes (Graen \& Uhl-Bien, 1995; Liden, Sparrow \& Wayne, 1997; Schriesheim, Castro \& Cogliser, 1999), that is, the positive organizational and individual outcomes result in a high-quality exchange between leaders and followers. Positive results include higher personal performance and operational performance, but also ascendants for commitment to the organization, job satisfaction, organizational behaviour, as well as a weaker desire to leave the organization (Gerstner \& Day, 1997; Schriesheim et al, 1999; Wayne et al., 1997). LMX theory describes the relationship 
of employees and their supervisors in a continuum from low to high exchange, and it is therefore measured as a continuous variable, because numerous studies have shown that it is more likely established either high or low exchange relationship with followers (Yukl, 2006). A high-quality exchange requires both parties to accept their mutual interests and have the agreement to carry out common goals. In contrast, low-quality exchange characterized by a follower has a limited level of communication with their leader and a limited scope of responsibility.

\subsection{Organizational commitment and turnover intent}

Organizational commitment is extremely useful because it has a major impact on the successful performance of an organization. It is a measure of the strength of-identification of the employee with purposes and values of the organization (Mowday et al., 1982; Meyer \& Allen, 1997), which is defined as a psychological condition for the relationship of an employee with the organization that influences the decision of the employee to stay in a specific organization (Meyer $\&$ Allen, 1993). The importance of this construct is reflected in the ability to predict, based on the level of its value, the concrete results such as the results of employees and their behaviour, which has practical significance for the organization.

The three-component construct is composed of emotional (affective), normative and continuous commitment. Affective commitment is defined as the emotional attachment, identification and involvement the individual employees feel towards the association, the trust in the organizational values, readiness to help the organization to achieve its objectives and to develop high quality and rational relationship with the management (Porter et al, 1974; Meyer \& Allen 1991). Normative commitment is based on Weiner's (1982) study of internalization of norms of loyalty to organizations and it is more theoretical than empirical but depended on social circumstances and external pressures (family, environment), as well as on the sense of obligation to their workplace (loyalty). It is defined by a strong emphasis on social obligations and the tendency of individuals (Yang, 2008). Continuous commitment is the willingness to stay in the organization because of the lack of other available alternatives, i.e. employees do not stay in the organization because they want to, but because they have to (Meyer \& Allen, 1991, 1997). Some scholars (Stinglhamber et al, 2002; Bentein et al, 2005) divide continuous commitment into two sub-dimensions - the experience of great sacrifice associated with leaving the organization and the lack of alternative employment opportunities.

In most studies commitment as a determination is treated as a statistical variable (Bentein et al, 2005). Wayne and his associates $(2002,2009)$ make a positive correlation between LMX and commitment in the sense that high-quality relationships promote employee's commitment to the organization and building good relations with followers in order to increase loyalty to the leaders. Affective commitment is considered as the strongest and most powerful form of organizational commitment (Jax, 2002), while all three constructs correlate negatively with turnover intent (Cooper-Hakim \& Viswesvaran, 2005; Golden and Veiga, 2008).

Changing staff members has serious consequences on the efficiency of the organization. The time necessary to find the right employees and the time it takes for new employees to reach the maximum level of operational performance can sometimes be an obstacle in achieving organizational goals. The intention to leave an organization is a psychological process which an individual goes through when considering alternative employment opportunities due to dissatisfaction with the current organization (Martin, 2011). This is a process that precedes realization - quitting a job. Most research studies focus on the very intention of changing jobs because it is easier for 
employees to express their intention to leave the organization than to really quit (Kim et al., 2010), regardless of the type of organization. A key challenge to organizations is to retain skilled workers (Griffeth et al., 2000). The individual predictors and organizational predictors (organizational commitment, job satisfaction, etc.) show a significant relationship with turnover intent.

The correlation between turnover intent and the level of LMX relationships gave inconsistent outcomes. Collins (2010) suggests that the nature of the relationship between leaders and followers and intention to leave „remains ambiguous”. Some studies noted a linear relationship between LMX and employee turnover intent (Morrow et al., 2005). Also, empirical findings showing a significant negative correlation between the quality of leaders and followers exchange and intentions to leave were recorded by Sparrow (1994), Wayne and his associates (1997), Erdogan and Liden (2002) and Sparr and Sonntag (2008), while others did not find any correlation (Vecchio et al., 1986). In summary, an employee who has a weak relationship with his/her superior(s), is more likely to indicate the intention to leave, than those employed with a high quality of exchange (Gerstner \& Day, 1997; Schyns et al., 2007).

$\mathbf{H}_{1}$ : There is a significant correlation between the level of LMX and organizational commitment in the hospitality and public sectors.

$\mathbf{H}_{2}$ : Construct LMX is negatively correlated with the turnover intent in the hospitality and public sectors.

$\mathbf{H}_{3}$ : Dimensions of organizational commitment as predictors of the level of LMX in hospitality and public sectors.

$\mathbf{H}_{4}$ : Predictor's turnover intent negatively affects the level of LMX in hospitality and public sectors.

\section{METHODOLOGY}

\subsection{Instruments}

Leader-member exchange questionnaire (LMX-7) - measuring the quality of the employee relationship with the superior according to Graen and Uhl-Bien (1995) is most commonly used to study theoretical questions, and it is filled by both the leaders and followers. The quality of leaders and followers exchange was measured by the LMX-7 questionnaire with the standard fivepoint Likert's scale (strongly disagree - strongly agree). Respondents were offered seven statements (items). The questionnaire is homogeneous and has a single dimension. Scores obtained by LMX-7 have the following meaning: very high from 30-35, high from 25-29, medium from 20-24, low from 15-19, and very low from 7-14. Results in the upper range point to a stronger, better exchange of leaders and followers, and results in lower ranges indicate the exchange of lower quality. Cronbach alpha for this questionnaire is very high (at $\alpha=.94$ ).

Organizational commitment (OC) questionnaire - measuring the dimensions of organizational commitment according to Porter and his associates (1974) - affective (emotional), normative and continuous commitment - consists of five items (15 in total) which were measured on Likert's scale (1-strongly disagree to 5-strongly agree). It contains seven reverse-coded items. Emotional commitment has the highest alpha reliability coefficient $(\alpha=.82)$.

Turnover Intent (TI) - the measurement of intention to leave the organization by Mobley, Horner and Hollingsworth (1978). The turnover intent was measured with three questions on a five- 
point Likert's scale (1-very bad to 5-excellent). The minimum score is 3 and the maximum is 15. Higher scores indicate a high intention of leaving the current job. Cronbach alpha for questionnaire is high $(\alpha=.88)$.

We also used control variables such as gender, age, years of service with the current employer, total years of service and level of education.

\subsection{Procedure}

The paper examined the quality correlates of the relationship between the employees and their superiors, as well as the regression model in the hospitality and public sector according to the LMX model. We also examined the relationship between the leaders and followers and determined its connection with the dedication to work and willingness to leave the job. Testing the organizational factors that have a predictive effect used organizational commitment and turnover intent. The results of performance test of those relationships are shown separately for hospitality and public sector, bearing in mind that organization in the hospitality sector is characterized by a high level of entrepreneurial orientation and a high level of competition on the market. The sample size included 200 respondents from hospitality (travel agencies, hotels, restaurants, coffee bars and wineries) and public sector (city and municipal administration, tourism organizations, public utilities, health centres, hospitals, elementary schools and colleges) in Serbia. The resulting data were analyzed using the SPSS 22.0 statistical package. Cronbach alpha was calculated for all instruments in order to confirm the reliability of the questionnaire.

\subsection{Sample}

Women accounted for $64 \%$, i.e. they made the majority of subjects in the sample. The largest number of respondents (94) were aged from 30 to 44 , while $27.5 \%$ of respondents were older than 45. A total of 8 respondents (4\%) did not comment on their age (four from each sector). The questionnaires were offered to persons with six levels of education: elementary school, high school, college, university, Master (MSc) and Ph.D. The most common level is university education with 111 or $55.5 \%$ of the respondents. Only one respondent has an elementary school and has been employed in the hospitality sector (coffee shop). Also, most employees with secondary education are in restaurants and coffee shops, while in hotels (reception) most employees are with the university education. The average length of service with the current employer for the hospitality sector is 5.3 years, and in the public sector, it makes 10.4 years. One employee in the hospitality sector and four employees in the public sector have more than 30 years of service in the current organization.

\section{RESEARCH RESULTS}

Descriptive statistics and correlation of variables are shown in Table 1 for both sectors. Employees in both sectors have characterized the efficiency of their working relations with superiors as good, and stated that the superior recognize their potential and is ready to help them get ,pulled out of the pulley". Distribution results in the hospitality sector in this dimension are negatively skewed, and employees have higher scores for specific answers regarding the level of LMX. On the other hand, public sector employees have a normal distribution, i.e. have relatively uniform answers regarding the level of LMX. Employees in the hospitality sector show greater emotional attachment to the organization in which they work, as opposed to the public sector employees 
who are not fully emotionally attached to the organization. Based on the results of continuous commitment it can be concluded that there are no significant differences between the sectors surveyed. Such responses could be explained with general conditions on the labour market and the economic crisis in which Serbia is. Other reasons may be that employees are unsure or undecided whether they want to stay in the current organization. It may be also assumed that employees do not feel comfortable discovering their true perception, especially when it comes to public sector employees. Considering that continuous commitment is based on benefits, people stay in their organization since they need to. The results for the normative commitment indicate that respondents in the public sector are not willing to commit to staying with the organization because of obligation or loyalty; this can be connected with an announcement of rationalization in the public sector made quite a long time ago.

Employees in both sectors have expressed different views on three findings of turnover intent, which indicates the range value of 4.00. One of the assumptions is that it is the result of the influence of external factors (economic instability, insufficient number of available alternatives and others). Although the hospitality sector is characterized by frequent job changes and highly extensive changes are being prepared in the public sector, the deviations in the perception of employees show minor differences. According to the results, the t-test (Table 2) showed that data obtained for hospitality were higher than for the public sector, and the size effect was medium for LMX and emotional commitment, and for the normative commitment it was small, according to the following:

- LMX hospitality $(\mathrm{M}=3.40, \mathrm{SD}=1.00)$ higher than public $(\mathrm{M}=2.89, \mathrm{SD}=1.02)$, $\mathrm{t}(198)=3.54, \rho<.05, d=.06$;

- AC hospitality $(\mathrm{M}=3.68, \mathrm{SD}=.89)$ higher than public $(\mathrm{M}=3.22, \mathrm{SD}=.90)$, $\mathrm{t}(198)=3.63, \rho<.05, d=.06$;

- $\mathrm{NC}$ hospitality $(\mathrm{M}=3.16, \mathrm{SD}=.54)$ higher than public $(\mathrm{M}=2.84, \mathrm{SD}=.55)$, $\mathrm{t}(198)=4.21, \rho<.05, d=.01$;

Table 1. Mean, SD, correlation

\begin{tabular}{|l|c|c|c|}
\hline Variables & M & SD & LMX \\
Hospitality & \multicolumn{3}{|c|}{} \\
\hline Age & 33.67 & 9.69 & \\
\hline Gender & .58 & .50 & 1 \\
\hline LMX & 3.40 & 1.01 & $.49^{* *}$ \\
\hline AC & 3.68 & .89 & .54 \\
\hline NC & 3.16 & .67 & $-.60^{* *}$ \\
\hline CC & 3.20 & 1.08 & \\
\hline TI & 2.36 & & \\
\hline
\end{tabular}

\begin{tabular}{|c|c|c|c|}
\hline \multicolumn{4}{|l|}{ Public } \\
\hline Age & 42.63 & 9.25 & \\
\hline Gender & .70 & .46 & \\
\hline LMX & 2.89 & 1.02 & 1 \\
\hline $\mathrm{AC}$ & 3.22 & .90 & $.63 * *$ \\
\hline $\mathrm{NC}$ & 2.84 & .55 & \\
\hline $\mathrm{CC}$ & 3.28 & .74 & \\
\hline TI & 2.41 & 1.18 & $-.44 * *$ \\
\hline
\end{tabular}

Correlation is significant at the 0.05 level; ${ }^{* *}$ Correlation is significant at the 0.01 level; LMX-Leader member exchange; AC-affective commitment; CC-continuous commitment; NC-normative commitment; TI-turnover intent; M-mean; SD-standard deviation, $\mathrm{N}=100$ for each sector.

Source: Authors' calculations 
The test showed that there were no sectoral differences when it comes to turnover intent. Determining the size effect between the groups was calculated using t-test (Rosnowo et al., 1996), and was interpreted according to the guidelines suggested by Cohen (Cohen, 1988).

Table 2. T-test

\begin{tabular}{|c|c|c|c|c|c|}
\hline Variables & F & $\rho$ & t & df & $\rho$ \\
\hline LMX & .29 & .59 & 3.54 & 198 & .00 \\
\hline AC & .04 & .84 & 3.63 & 198 & .00 \\
\hline NC & .27 & .61 & 4.21 & 198 & .00 \\
\hline CC & .36 & .55 & -.76 & 198 & .45 \\
\hline TI & .90 & .35 & -.31 & 198 & .76 \\
\hline
\end{tabular}

F-statistics; $\rho$-value (Sig.) $>.05$; t-value of t-test; df-degrees of freedom; $\rho$-value $(\mathrm{Sig})<.05$.

Source: Authors' calculations

Multiple regression model shown in Table 3 where LMX is the criterion variable, and predictor of organizational commitment and intention to leave the current organization.

Table 3. Multiple regressions model

\begin{tabular}{|c|c|c|c|c|c|c|c|}
\hline \multicolumn{2}{|c|}{ Variables } & $\mathbf{R}^{2}$ & $\mathbf{F}$ & $\rho$ & $\beta$ & $\mathbf{t}$ & $\rho$ \\
\hline \multirow{2}{*}{ AC } & Hospitality & .24 & 30.16 & \multirow{2}{*}{.00} & .49 & 5.49 & \multirow{2}{*}{.00} \\
\hline & Public & .39 & 63.04 & & .63 & 7.94 & \\
\hline \multirow{2}{*}{ NC } & Hospitality & .00 & .02 & .88 & & & \\
\hline & Public & .02 & 1.69 & .20 & & & \\
\hline \multirow{2}{*}{$\mathrm{CC}$} & Hospitality & .02 & 1.54 & .22 & & & \\
\hline & Public & .00 & .08 & .78 & & & \\
\hline \multirow{2}{*}{ TI } & Hospitality & .36 & 54.96 & \multirow{2}{*}{.00} & -.60 & -7.41 & \multirow{2}{*}{.00} \\
\hline & Public & .19 & 23.51 & & -.44 & -4.85 & \\
\hline
\end{tabular}

Dependent variable is LMX; significant at the 0.05 level ; $\mathrm{R}^{2}$ - coefficient determination; $\rho$-value $<.05$; $\beta$-beta standard regression coefficient.

Source: Authors' calculations

\section{DISCUSSION}

A significant correlation coefficient in both sectors was recorded in an emotional commitment to the level of exchange between leaders and followers. In hospitality sector Pearson's correlation coefficient was moderate $-\mathrm{r}(100)=.49, \rho<.01$, while in the public sector it was high $\mathrm{r}(100)=.63, \rho<.01$. The first reason is that superiors know that the employees who enjoy their confidence respond favourably or respond positively to the requests, which increases the total commitment to the organization (Cogliser et. al, 2009). Another reason is that employees who have a high commitment to their work, have a good relationship with their superiors (Graen, Scandura, 1987). Fisher's $z^{4}$ transformation of emotional commitment and level of LMX between hospitality and the public sector has shown that there is no statistically significant difference $(\mathrm{z}=-1.43)$. Hypothesis one was partially supported.

$4 \quad$ The comparison of the difference between the correlation coefficients for hospitality and public sector is calculated using the Fisher's $Z$ transformation test, namely by calculating the $Z$ value for assessment of significant differences between the two correlation coefficients $r$ (a) and $r(b)$ in two independent samples. If $\mathrm{r}$ (a) is larger than $\mathrm{r}(\mathrm{b})$, the resulting value of $\mathrm{z}$ has a positive sign, otherwise it will be negative. If the value in absolute values is greater than 1.96 the differences between correlation coefficients are statistically significant. 
The main objective of this paper was to determine correlates of quality at the organizational level in leader-follower exchange and compare the obtained results in the studied service sectors. The affective commitment to the organization shows a correlation with the level of leaders - members exchange in both sectors. Working in travel agencies, hotels, restaurants or cafes indicates that employees are willing to assist the organizations in achieving their objectives, and thus to develop good relations with superiors. In the public sector, employees showed a significantly higher relation between emotional commitment and level of LMX. Consequences arising from such integration can enable employee advancement, different benefits and preferential status in the organization in relation to others.

The connection between the level of leaders - members exchange and turnover intent was highly negative in the hospitality sector $-\mathrm{r}(100)=-.60, \rho<.01$, while in the public sector it was moderately negative $-\mathrm{r}(100)=-.44, \rho<.01$. When employees have a low quality of LMX exchange, turnover intent is stronger than that of employees with higher leaders and followers exchange (Gerstner \& Day, 1997). On the other hand, in some studies, the researchers reported that the ratio may be ,circular” between the levels of LMX and turnover intent (Morrow et al., 2005; Collins, 2007). Both extremes of low and high quality of exchanges between leaders and employees tend to increase the intention of changing jobs. In the first case, a sense of „negligence” in the organization, and the second, a sense of great importance in the organization. However, according to Collins (2007), employees with a very low quality of exchanges are less likely to change jobs or quit because of the lack of alternatives for a new job. Fisher's transformation with turnover intent and the level of LMX between the hospitality and public sector showed no statistically significant difference $(\mathrm{z}=1.53)$. Hypothesis two was fully supported.

The cause for intention to leave can be the work environment, management, salary system, dissatisfaction, and personal or organizational problems. If employees feel they have the opportunity to leave the current organization and find another job that will probably stimulate the turnover intent. In many cases, the researchers (Mobley, 1977; Mitchell, 1981; Kim et al., 2010) examined the actual turnovers. For this sample, the respondents from the hospitality sector have shown to have a significant negative correlation between turnover intent and the level of exchanges with their leader. Similar ratios are in the public sector. In the hospitality sector, the advancement inability, length of the working week and working hours are predictors of intention to leave the organization. On the other hand, public sector employees have the pressure of rationalization that was announced a few years ago and among older responders, this is increased by the absence of available alternatives, which is likely to cause the results to be higher for individual statements in the questionnaire.

Based on the results for the hospitality sector, there is a correlation between criterion and predictor variables (organizational commitment). The dimension of emotional commitment shows statistically significant coefficient of the beta with $\operatorname{LMX}\left(\mathrm{R}^{2}=.24, \mathrm{~F}(1,98)=30.16, \rho<.05\right)$, i.e. medium intensity and positive sign. This indicates that hospitality sector employees have a favourable treatment which leads to affective commitment to the organization. However, a very small number of employees in some organizations have no other alternatives for employment in other organizations with similar working conditions. In three-dimensional model of organizational commitment in the public sector only emotional commitment has a statistically significant contribution to the prediction of $\operatorname{LMX}\left(\mathrm{R}^{2}=.39, \mathrm{~F}(1,98)=63.04, \rho<.05\right)$, i.e. high intensity and positive sign. This shows that despite numerous advantages (length of annual leave, paid leave, various fees, etc.) public sector is still under the constant pressure of changes that should 
follow in the form of important public sector reforms. This is indicated by $39 \%$ of the criterion variability, and that is one of the indicators that the superiors will decide on redundancies. $\mathrm{Hy}$ pothesis three was partially supported in both sectors.

The analysis shows that emotional attachment is a predictor of the quality level of exchanges between leaders and followers in the hospitality sector. The majority of the hospitality organization has a relatively small number of employees and strong relationships that are established among employees, including the relationship with the superiors. Therefore, the affective commitment to the organization in this sector is largely based on a good relationship with co-workers, including the superiors. Thus, the growth of affective commitment is accompanied by the growth of quality of the relationships with superiors. In the public sector, affective commitment is also a predictor of the LMX level. Numerous factors affect this result of the regression analysis. Primarily, the advantage of the public sector as compared to other organizations with respect of usual salary, the length of annual leave, sick leave or paid leave, reimbursement of transport costs to and from work and other things. Some of those benefits are the responsibility of leaders (for example, training, education, business trips, etc.).

Also, the results indicate that the turnover intent (high intensity and negative sign) affects the level of LMX quality in the hospitality sector $\left(\mathrm{R}^{2}=.36, \mathrm{~F}(1,98)=54.96, \rho<.05\right)$, but it is not caused by a poor relationship with superiors in all cases. This paper points to the problems of leaving a job in the hospitality sector. The intention to leave affects negatively (smaller intensity) the level of LMX quality in the public sector $\left(\mathrm{R}^{2}=.19, \mathrm{~F}(1,98)=23.51, \rho<.05\right)$ and employees are more influenced by the announced layoffs, but the real desire of change and the percentage of variability criterion variable is low (19\%). Hypothesis four is fully supported.

In this sample size taken for the hospitality sector, the turnover intent variable significantly contributes to the prediction of negative results of the leaders and employees exchange. This can be attributed to the fact that the relationship that employees have with their superiors in the hospitality sector has a certain quality, but also that there is a higher degree of tolerance for the overall market situation. In the same sample, the public sector also showed that the intention to leave contributes significantly negatively to the quality level of LMX, as confirmed by studies in the US and Europe (Erdogan, 2002; Shirley, 2003; Sparr \& Sonnentag, 2008; and others). In the case of the public sector, the situation is somewhat different. Years of work in the „safe area" of public administration or public companies have been brought into imbalance by the announced numerous dismissals and reorganization of the public sector.

\section{FUTURE RESEARCH DIRECTIONS}

The leader is the one who stands in front of his/her followers. The contribution of this research is the development of LMX theory in the hospitality and public sector from the point of quality of the leader-follower exchange correlations. We selected the correlations we assumed to have a significant predictive value for the LMX relation quality, as well as those that will result in a high or low LMX value. Also, the presented results can be used to avoid all the negative consequences of organizational performance.

Organizational commitment and turnover intent are important factors in service sectors. The number of samples and constructs (such as job satisfaction, organization justice, personal traits, etc.) should be increased, in order to examine the relations more closely in future research. 


\section{CONCLUSION}

The hospitality sector belongs to the private sector where the managers or owners organize the work in accordance with their capabilities and knowledge. In addition to many external factors (economic power of service users, free time, length of vacation, lifestyle), the development of the team of followers also affects the achievement of organizational goals. Although the largescale organizations such as hotels, restaurants and tour operators are the leaders in this sector, in organizations with fewer employees, the leader plays an important role. On the other hand, the public sector has its own functioning characteristics and its most important feature is to serve the citizens. We are witnessing many complaints that citizens have regarding the functioning of the public sector, from providing administration services (taxes, personal documents, etc.) to the functioning of public and public utility organizations. In order to increase accountability and raise the quality of services provided to citizens, it is necessary to reorganize and depoliticize the public sector in Serbia.

Employees should be able to respond effectively to the requirements and deliver quality services. This largely depends on the ability and capacity of the leader to support and influence his/her employees in achieving the organization's objectives. The quality of the relationship between leaders and followers produces a range of consequences such as a positive correlation with the organization while minimizing the intention among the employees to change or leave the organization. Resources (people and money) in the service sector and business conditions are essential for the survival of the organization in today's market. The indicator of the quality of the relationship with the superiors is the emotional attachment of employees to the organization, which indicates that employees in both sectors are willing to help the organization. In the case of the public sector, employees appear to be very restrained although they have significant advantages compared to other organizations.

As a consequence of the lower quality of the relationship with a leader, some respondents pointed out that they are thinking about changing the job. The intention to leave is negatively correlated with LMX in both sectors. Employees in the hospitality sector strive for better working conditions (salary, promotion, working hours), whereas employees in the public sector are in an uncertain position because the reorganization plan has not been adopted yet. According to the type of organizations it has been shown in both service sectors that employees have significantly different relationships with their superiors, because different rules of conduct are in place and because systems of functioning of the organization are different.

\section{REFERENCES}

Bentein, K., Vandenberg, R., Vandenberghe, C., \& Stinglhamber, F. (2005). The role of change in the relationship between commitment and turnover: A latent growth modelling approach. Journal of Applied Psychology, 90, 468-482. https://doi.org/10.1037/0021-9010.90.3.468

Blau, P. M. (1964). Exchange and power in social life. New York: John Wiley.

Cogliser, C. C., Schriesheim, C. A., Scandura, T., \& Gardner, W. L. (2009). Balance in leader and follower perceptions of leader member exchange: Relationships with performance and work attitudes. The Leadership Quarterly, 20(3), 452 465. https://doi.org/10.1016/j.leaqua.2009.03.010

Cohen, J. (1988). Statistical power analysis for the behavioural sciences (2nd ed.). Hillsdale, NJ: Lawrence Earlbaum Associates. 
Collins, S. (2007). Statutory Social Workers: Stress, Job Satisfaction, Coping, Social Support and Individual Differences. British Journal of Social Work, 38(6), 1173-1193. https://doi.org/

Collins, M. (2010). The effect of psychological contract fulfillment on manager turnover intentions and its role as a mediator in a casual, limited-service restaurant environment. International Journal of Hospitality Management, 29(4), 736-742.https://doi.org/10.1093/bjsw/bcm047

Cooper-Hakim, A., \& Viswesvaran, C. (2005). The construct of work commitment: Testing an integrative framework. Psychological Bulletin, 131(2), 241-259.https://doi.org/10.1037/00332909.131.2.241

Cropanzano, R., \& Mitchell, M. S. (2005). Social Exchange Theory: An Interdisciplinary Review. Journal of Management, 31(6), 874-900. https://doi.org/10.1177/0149206305279602

Dansereau, F., Graen, G., \& Haga, W. (1975). A vertical dyad linkage approach to leadership with informal organizations. Organizational Behavior and Human Performance,13, 46-78.

Day, D. V., \& Miscenko, D. (2015). Leader-Member Exchange Theory (LMX): Construct Evolution, Contributions, and Future Prospects for Advencing Leadership Theory. The Oxford Handbooks of LMX (online). www.oxfordhandbooks.com

Dienesch, R.M., \& Liden, R.C. (1986). Leader-member exchange model of leadership: A critique and further development. Academy of Management Review, 11, 618-634.

Erdogan, B. (2002). Leader-member exchange differentiation fairness: evidence of new construct. Doctoral dissertation. University of IIlinois at Chicago. https://doi.org/

Erdogan, B. \& Bauer, T. N. (2015). Leader-member exchange theory. International Encyclopedia of the Social \& Behavioral Sciences, Second Edition, 641-647.https://doi.org/10.1016/B9780-08-097086-8.22010-2

Erdogan, B., \& Liden, R. C. (2002). Social exchanges in the workplace: A review of recent developments and future research directions in leader-member exchange theory. In L. L. Neider, \& C. A. Schriesheim (Eds.): Leadership. Greenwich, CT: Information Age. 65-114.https://doi. org/10.1037/0021-9010.91.2.298

Ferris, G. R. (1985). Role of leadership in the employee withdrawal process: A constructive replication. Journal of Applied Psychology, 70, 777-781.https://doi.org/10.1037/0021-9010.70.4.777

Gerstner, C. R., \& Day, D. V. (1997). Meta-Analytic Review of Leader-Member Exchange Theory: Correlates and Construct Issues. Journal of Applied Psychology, 82, 827-844.

Golden, T. D., \& Viega, J. P. (2008). The impact of superior-subordinate relationships on the commitment, job satisfaction and performance of virtual work. Leadership Quarterly, 19, 77-88. https://doi.org/10.1016/j.leaqua.2007.12.009

Graen, B. G. (1976). Role-making processes within complex organizations. In M. Dunnette (ed.). Handbook of Industrial and Organizational Psychology. Chicago: Rand McNally.

Graen, B. G., \& Cashman, J. (1975). A role making model of leadership in formal organizations: A developmental approach. In J. Hunt, L. Larson (eds). Leadership Frontiers. Kent, OH: Comparative Administration Research Institute, Kent State University.https://doi.org/10.31410/ tmt.2019.617

Graen, B. G., \& Scandura, T. A. (1987). Toward a psychology of dyadic organizing. Research in Organizational Behavior, 9, 175-208.https://doi.org/10.31410/tmt.2019.617

Graen, B. G., \& Uhl-Bien, M. (1995). Relationship-Based Approach to Leadership: Development of Leader-Member Exchange (LMX) Theory of Leadership over 25 Years: Applying a Multi-Level Multi-Domain Perspective, Management Department Faculty Publications, Paper 57, Nebraska. https://doi.org/10.31410/tmt.2019.617

Griffeth, R., Hom, P., \& Gaertner, S. (2000). A meta-analysis of antecedents and correlates of employee turnover: Update, moderator tests, and research implications for the next millennium. Journal of Management, 26, 463-488. 
Jax, S. M. (2002). Organizational psychology: A scientist-practitioner approach. New York, NY: Wiley.

Hollander, E.P., \& Julian, J.W. (1969). Contemporary trends in the analysis of leadership processes, Psychological Bulletin, 71(5), 387-397.

Kim, B. P., Lee, G., \& Carlson, K. D. (2010). An examination of the nature of the relationship between Leader-Member-Exchange (LMX) and turnover intent at different organizational levels. International Journal of Hospitality Management, 29(4), 591-597.https://doi.org/10.1016/j. ijhm.2009.10.025

Liden, R. C., Sparrowe, R. T., \& Wayne, S. J. (1997). Leader-Member Exchange Theory: The Past and Potential for the Future. In. G. R. Ferris (Ed.), Research in personnel and human resources management. Greenwich, CT: JAI Press, Vol. 15, 47-120.

Martin, M. J. (2011). Influence of Human Resource Practices on Employee Intention to Quit, Dissertation submitted to the faculty of Virginia Polytechnic Institute and State University in partial fulfillment of the requirements for the degree of Doctor of Philosophy.

Meyer, J. P., \& Allen, N. J. (1991). A three-component conceptualization of organizational commitment. Human Resource Management Review, 1(1), 61-89.https://doi.org/10.1016/10534822(91)90011-Z

Meyer, J. P., \& Allen, N. J., Smith, C. A. (1993). Commitment to organizations and occupations: Extension and test of a three-component conceptualization. Journal of Applied Psychology, 78, 538-551.https://doi.org/10.1037/0021-9010.78.4.538

Meyer, J. P., \& Allen, N. J. (1997). Commitment in the workplace: Theory, Research, and Application.Thousand Oaks, CA: Sage Publications.

Mitchell, T.R., Holtom, B.C., Lee, T.W., Sablynski, C.J., Mitchell, T.R., Lee, T.W., \& Sablynski, C.J. (2001), Why people stay: Using job embeddedness to predict voluntary turnover. The Academy of Management Journal, 44(6), 1102-1121.https://doi.org/10.2307/3069391

Mobley, W. H. (1977). Intermediate linkages in the relationship between job satisfaction and employee turnover. Journal of Applied Psychology, 62(2), 237-240. http://dx.doi.org/10.1037/00219010.62.2.237

Mobley, W. H., Horner, S.O., \& Hollingsworth, A.T. (1978). An evaluation of precursors of hospital employee turnover. Journal of Applied Psychology, 63(4), 408-414.https://doi. org/10.1037/0021-9010.63.4.408

Morrow, P., Suzuki, Y., Crum, M., Ruben, R., \& Pautsch, G. (2005). The role of leader-member exchange in high turnover work environments. Journal of Managerial Psychology, 20(8), 681-694. https://doi.org/10.1108/02683940510631444

Mowday R., Porter L., \& Steers R. (1982). Employee organization Linkages: The Psychology of Commitment, Absenteeism, and Turnover. Academic Press, New York, NY.

Northouse, P. G. (2001). Leadership: Theory and Practice (2nd ed.), Thousand Oake, CA: Sage Publications Inc.

Porter, L., Steer, R., Mowday, R., \& Boulian, P. (1974). Organizational commitment, job satisfaction, and turnover among psychiatric technicians. Journal of Applied Psychology, Vol. 59, 603-609. https://doi.org/

Rosnow, R. L., \& Rosenthal, R. (1996). Computing contrasts, effect sizes, and counter nulls on other people's published data: General procedures for research consumers. Psychological Methods, 1(4), 331-340.

Schriesheim, C. A., Castro, S. L., \& Cogliser, C. C. (1999). Leader-Member Exchange (LMX) Research: A Comprehensive Review of Theory, Measurement, and Data-Analytic Practices. Leadership Quarterly, 10, 63-113. 
Schyns, B., Torka, N., \& Gossling, T. (2007). Turnover intention and preparedness for change: Exploring leader-member exchange and occupational self-efficacy as antecedents of two employability predictors. Career Development International, 12(7), 660-679.https://doi. org/10.1108/13620430710834413

Shirly, C. (2003). A study of effects of Leader-Member Exchange (LMX) on subordinate employment satisfaction and loyalty in the newly "reinvented" federal sector. Doctoral dicissertation. Nova Southeastern University.

Sparr, J. L., \& Sonnentag, S. (2008). Fairness perceptions of supervisor feedback, LMX, and employee well-being at work. European Journal of Work and Organizational Psychology, 17, 198-225. https://doi.org/10.1080/13594320701743590

Sparrowe, R. T. (1994). Empowerment in the hospitality industry: An exploration of antecedents and outcomes. Journal of Hospitality \& Tourism Research, 17(3), 51-73.

Stinglhamber, F., Bentein, K., \& Vandenberghe, C. (2002). Extension of the three-component model of commitment to five foci: Development of measures and substantive test. European Journal of Psychological Assessment, 18, 123-138. https://doi.org/10.1027//1015-5759.18.2.123

Tubay, J., B. (2019). The Role of Job Satisfaction and Organizational Commitment on Turnover Intentions of Accounting Professionals in Big 3 Auditing Firms in the Philippines with Moderating Effect of Leader-member Exchange. International Review of Management and Marketing, 9(2), 84-88.https://doi.org/10.32479/irmm.7632

Uhl-Bein, M. (2006). Relational Leadership Theory. Exploring the social processes of leadership and organizing. Leadership Quarterly, 17(6), 654-676.https://doi.org/10.1016/j.leaqua.2006.10.007

Vecchio, R. P., Griffeth, R. W., \& Hom, P. W. (1986). The predictive utility of the vertical dyad linkage approach. Journal of Social Psychology, 126, 617-625. https://doi.org/10.1080/00224 545.1986.9713634

Wayne, S. J., \& Green, S. A. (1993). The effects of leader-member exchange on employee citizenship and impression management behavior. Human Relations, 46, 1431-1440.https://doi. org/10.1177/001872679304601204

Wayne, S. J., Shore, L. M., \& Linden, R. C. (1997). Perceived Organizational Support and Leader-Member Exchange: A Social Exchange Perspective. Academy of Management Journal, 40, 82-111.https://doi.org/10.2307/257021orhttps://www.jstor.org/stable/257021

Wayne, S. J., Shore, L. M., Bommer, W. H., \& Tetrick, L. E. (2002). The role of fair treatment and rewards in perceptions of organizational support and leader-member exchange. Journal of Applied Psychology, 87, 590-598.https://doi.org/10.1037//0021-9010.87.3.590

Wayne, S. J., Coyle-Shapiro, J. A., Eisenberger, R., Liden, R. C., Rousseau, D. M., \& Shore, L. M. (2009). Social influences. In H. J. Klein, T. E. Becker, J. P. Meyer (Eds.), Commitment in organizations: Accumulated wisdom and new directions, 253-284. Mahwah, NJ: Lawrence Erlbaum.

Wiener, Y. (1982). Commitment in organizations: A normative view. The Academy of Management Review, 7(3), 418-428.

Yang, J.T. (2008). Effect of Newcomer Socialization on Organizational Commitment, Job Satisfaction, and Turnover Intention in The Hotel Industry. The Service Industry Journal, 28(4), 429-443.https://doi.org/10.1080/02642060801917430

Yukl, G. (2006). Leadership in Organizations (6th ed.). Upper Saddle River: Pearson Prentice Hall.https://doi.org/10.4236/oj1.2015.42006

Fisher' z transformation - http://vassarstats.net/rdiff.html April 2019.

http://scindeks.ceon.rs 2019. 
